\title{
Osteoarticular involvement in sickle cell disease
}

Geraldo Bezerra da Silva Junior ${ }^{1,2}$ Elizabeth De Francesco Daher ${ }^{1}$

Francisco Airton Castro da Rocha ${ }^{1}$

1 Department of Internal Medicine, Faculdade de Medicina, Universidade Federal do Ceará - UFC, Fortaleza, CE, Brazil

${ }^{2}$ School of Medicine, Centro de Ciências da Saúde, Universidade de Fortaleza - UNIFOR, Fortaleza, CE, Brazil
Conflict-of-interest disclosure:

The authors declare no competing

financial interest

Submitted: $11 / 28 / 2011$

Accepted: 12/21/2011

\section{Corresponding author:} Geraldo Bezerra da Silva Junior

Department of Internal Medicine, Faculdade de Medicina, Universidade Federal do Ceará Rua 25 de Março, 997

60060-120 - Fortaleza, CE, Brazil

Phone: 5585 3366-8052

geraldobezerraj@@yahoo.com.br

www.rbhh.org or www.scielo.br/rbhh

DOI: $10.5581 / 1516-8484.20120036$
The osteoarticular involvement in sickle cell disease has been poorly studied and it is mainly characterized by osteonecrosis, osteomyelitis and arthritis. The most frequent complications and those that require hospital care in sickle cell disease patients are painful vaso-occlusive crises and osteomyelitis. The deoxygenation and polymerization of hemoglobin $S$, which results in sickling and vascular occlusion, occur more often in tissues with low blood flow, such as in the bones. Bone microcirculation is a common place for erythrocyte sickling, which leads to thrombosis, infarct and necrosis. The pathogenesis of microvascular occlusion, the key event in painful crises, is complex and involves activation of leukocytes, platelets and endothelial cells, as well as hemoglobin $S$-containing red blood cells. Osteonecrosis is a frequent complication in sickle cell disease, with a painful and debilitating pattern. It is generally insidious and progressive, affecting mainly the hips (femur head) and shoulders (humeral head). Dactylitis, also known as hand-foot syndrome, is an acute vaso-occlusive complication characterized by pain and edema in both hands and feet, frequently with increased local temperature and erythema. Osteomyelitis is the most common form of joint infection in sickle cell disease. The occurrence of connective tissue diseases, including rheumatoid arthritis and systemic lupus erythematosus, has rarely been reported in patients with sickle cell disease. The treatment of these complications is mainly symptomatic, and more detailed studies are required to understand the pathophysiological mechanisms involved in the complications and propose more adequate and specific therapies.

Keywords: Anemia, sickle cell/complications; Bone diseases/etiology; Osteonecrosis; Osteomyelitis; Arthritis; Hemoglobin SC Disease.

\section{Introduction}

Sickle cell disease (SCD) is the most common inherited blood disease, with a worldwide distribution. ${ }^{(1)}$ The disease is characterized by vaso-occlusive crises due to the shape of the red blood cells consequent to the polymerization of one type of hemoglobin, called hemoglobin S, hemolytic anemia and increased susceptibility to infections. ${ }^{(2,3)}$

Several organs can be affected with alterations in the central nervous system, bone and joints, cardiovascular system, respiratory system, gastrointestinal tract, and kidneys, which increases morbidity and mortality in this group of patients. ${ }^{(1)}$ Osteoarticular involvement in SCD, marked mainly by osteonecrosis, osteomyelitis and arthritis, has been little studied. ${ }^{(4)}$

The physiopathology of osteoarticular involvement in SCD is still not completely understood, with the most important event being the occlusion of microvessels with consequent ischemia. This article describes the clinical features and physiopathology of different types of osteoarticular involvement in SCD and also discusses the main currently available therapeutic strategies for these complications.

\section{Osteoarticular manifestations}

Bones are the second most affected organs by SCD, after the spleen. Despite the importance of osteoarticular involvement in SCD, these complications are still little studied and the physiopathology of alterations is not fully understood.

The most frequent complications that require hospitalization in SCD patients are painful vaso-occlusive crises and osteomyelitis. ${ }^{(4)}$ In a study conducted in Africa, the leading cause of emergency care of children with SCD was painful osteoarticular crises observed in $58.6 \%$ of the cases. ${ }^{(5)}$

The main bone complications in acute SCD are summarized in Table 1.

The polymerization of deoxygenated hemoglobin $\mathrm{S}(\mathrm{Hb} \mathrm{S})$ occurs easier in tissues where blood flow is slow, such as in the bones, resulting in sickling and vascular occlusion. ${ }^{(6)}$ 
Table 1 - Acute bone complications in sickle cell disease

Painful vaso-occlusive crises

Osteomyelitis

Stress fracture

Orbital compression

Dental complications

Vertebral collapse

Medullary necrosis

Adapted from Almeida \& Roberts ${ }^{(4)}$

The bone microcirculation is a common site for the sickling of red blood cells leading to thrombosis, infarction and necrosis. ${ }^{(7)}$ The pathogenesis of microvascular occlusion, the key event in acute painful crises, is complex and involves the activation of leukocytes, platelets and endothelial cells, as well as red blood cells containing $\mathrm{Hb} \mathrm{S}$. These events can occur in virtually any organ, but they are particularly common in the bone marrow, resulting in spinal cord infarction, typically in the medullary cavity and the epiphyses. ${ }^{(4)}$ The reasons for the vulnerability of the bone marrow to microvascular occlusion are still uncertain, but may be partly due to bone marrow hypercellularity, leading to decreased blood flow and regional hypoxia. ${ }^{(8)}$

Chronic medullary hyperplasia due to bone marrow hypersolicitation caused by hemolysis causes bone alterations, as the expanded marrow spaces are filled by red marrow, which spreads through widened Haversian canals, invading the cortex and may extend to the periosteum. ${ }^{(6)}$ This results in the thinning of the cortical bone, marrow space enlargement and diffuse and irregular trabeculation.

Bone metabolism is regulated primarily by calcium and the regulating hormones, calcitonin and parathyroid hormone (PTH). Calcium is crucial for many processes in the body, including several signaling cascades, and thus, it is necessary to maintain serum levels under tight control.

Bones are the major reservoir of calcium, and bone remodeling is a crucial process for calcium regulation. The primary function of PTH is to maintain ionized calcium values within normal levels. PTH secretion increases when serum calcium levels drop below $8 \mathrm{mg} / \mathrm{dL}$. When calcium levels reach values above $10 \mathrm{mg} / \mathrm{dL}$, PTH secretion decreases physiologically. When this does not happen, hyperparathyroidism occurs. ${ }^{(9)}$

Other circulating factors, such as vitamin D, tumor necrosis factor- $\alpha$ (TNF- $\alpha$ ) and prostaglandins are also involved in the regulation of calcium balance. $\mathrm{PTH}$ provides calcium and phosphorus for mineral homeostasis through the stimulation of osteoclast activity and mineral resorption. Vitamin D also exerts an effect on bone remodeling and calcium homeostasis. Exposure to sunlight stimulates the endogenous production of vitamin D3 from 7-dehydrocholesterol. Subsequently, vitamin D3 is hydroxylated to 25hydroxyvitamin D in the liver and is then converted to 25hydroxyvitamin $\mathrm{D}$ in the kidneys. The active metabolite of 25-hydroxyvitamin D, 1,25-dihydroxyvitamin D (calcitriol) stimulates intestinal calcium absorption, supplying this mineral to maintain the bone metabolism.

Calcitonin is a regulatory hormone that acts independently of PTH and vitamin D with the ability to modulate serum calcium and phosphorus levels. Calcium is the main stimulus for the secretion of calcitonin. The secretion of calcitonin is stimulated by high levels calcium. The binding of calcitonin on osteoclast receptors leads to a decreased metabolic activity of osteoclasts. Osteoblasts secrete prostaglandin $\mathrm{E}_{2}\left(\mathrm{PGE}_{2}\right)$ in response to hormone stimuli. $\mathrm{PGE}_{2}$ stimulates bone formation and resorption and acts as a chemotactic stimulus for osteoclasts. ${ }^{(9)}$

There have been few studies on the metabolism of calcium and its effects on bone alterations in SCD patients. There is some evidence of a possible association between calcium metabolism alterations and the occurrence of osteoporosis in SCD. ${ }^{(10)}$

The bone alterations in SCD can be grouped into two main types: those associated with bone marrow hyperplasia due to chronic anemia and those associated with ischemic events such as bone necrosis and its complications. ${ }^{(11)}$

Clinically, patients complain of severe localized pain in one or more areas of the skeleton, which may be accompanied by edema and erythema in the infarction area. When the ischemia involves the epiphyses, there may be joint swelling, making it similar to septic arthritis. ${ }^{(4)}$

Cranial diploe prominence is observed in the skull, as well as flattening of the external and internal laminae and increased thickness of the frontal and parietal bones. The protrusion of the upper jaw leads to defective teeth, characterized by separation and angulations of the incisor teeth, in addition to problems in mouth closure. The vertebral bodies often suffer demineralization due to medullary hyperplasia, which causes vertebral flattening and biconcave "H" vertebrae (Figure 1). Osteoporosis and osteosclerosis of the terminal phalanges are also frequently observed. ${ }^{(6)}$

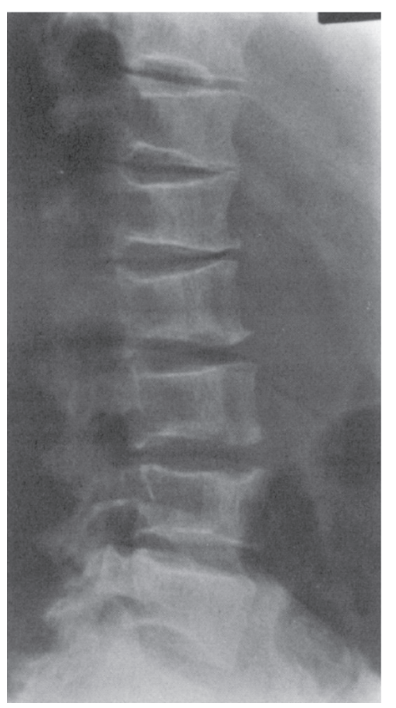

Figure 1 - X-ray of vertebral column showing biconcave vertebral body depressions in a patient with sickle cell disease. Reproduced from Huo et al. ${ }^{(1)}$ with the permission of the Yale Journal of Biology and Medicine 


\section{Osteonecrosis}

Osteonecrosis (or ischemic necrosis) is a frequent complication in SCD with painful and debilitating features. In areas of high prevalence of SCD, especially in tropical regions, SCD is a major cause of osteonecrosis of the femoral head. ${ }^{(12)}$

Osteonecrosis is usually an insidious and progressive disorder, affecting mainly the hip (femoral head) and shoulder (humeral head), as illustrated in Figures 2, 3, 4 \& 5. Approximately $50 \%$ of SCD patients have evidence of complications after the age of 30 years old. ${ }^{(6)}$ In children, $\mathrm{SCD}$ is the leading cause of osteonecrosis, with a prevalence of $3 \%$ before 15 years of age and an incidence of two cases per 100 patients/year. ${ }^{(6)}$ The vaso-occlusive crises affect mostly the long bones (especially the femur and humorous) but may also occur in the vertebrae and ribs, which can cause respiratory function complications. ${ }^{(13)}$ These vaso-occlusive crises are caused by obstructions in the microcirculation and are favored by some factors such as prolonged immobilization, physical exertion, sudden temperature changes, fever and dehydration. ${ }^{(13)}$

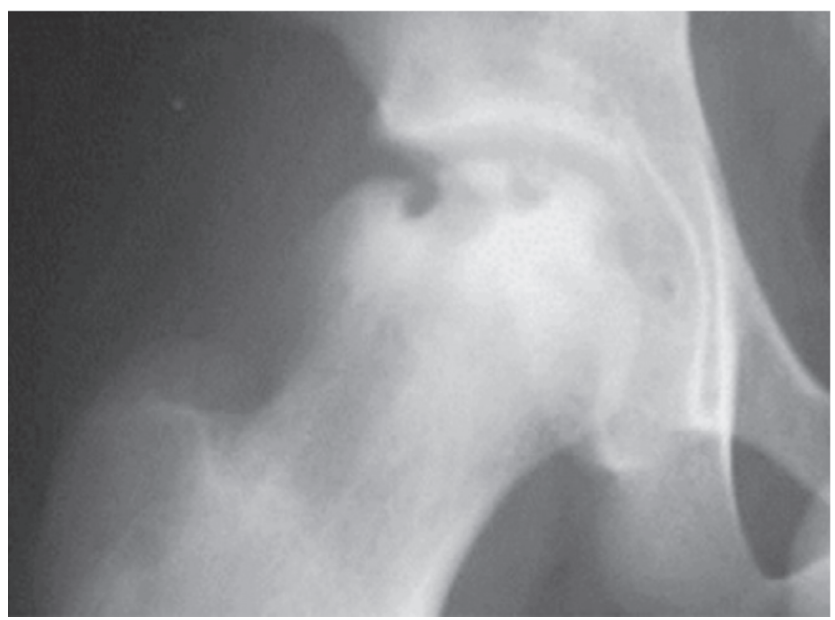

Figure 2 - X-ray of a 16-year-old patient with sickle cell disease showing necrosis of the femoral head. Reproduced from Mukisi-Mukaza et al. ${ }^{(12)}$ with permission of Elsevier B.V.

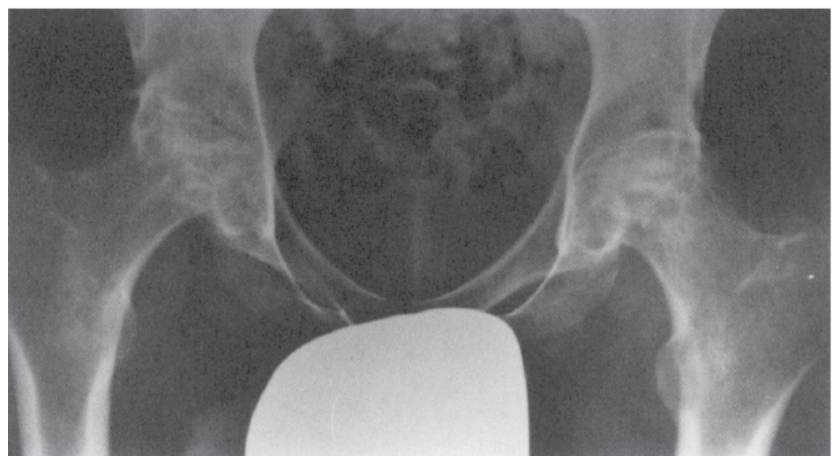

Figure 3 - X-ray showing bilateral osteonecrosis of the femur in patient with sickle cell disease. Reproduced from Huo et al. ${ }^{(11)}$ with the permission of the Yale Journal of Biology and Medicine

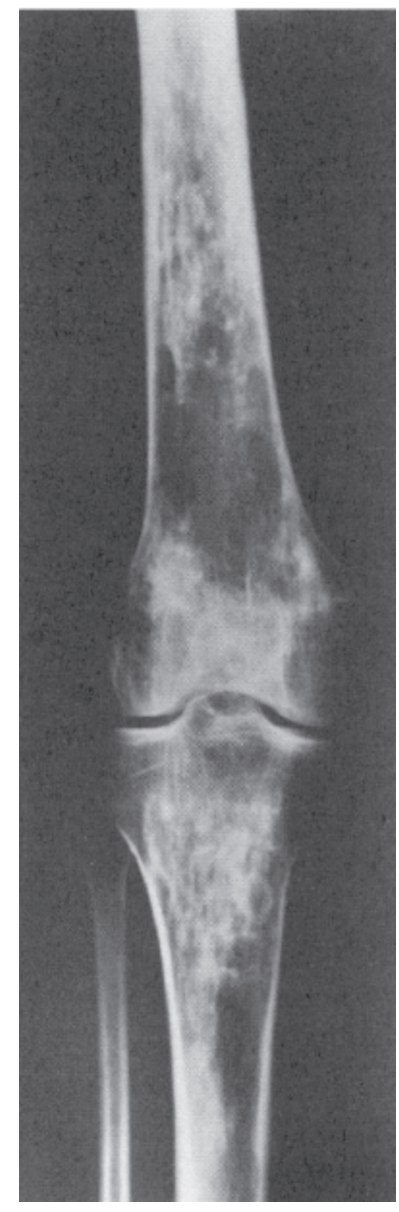

Figure 4 - X-ray showing multiple infarcts in the femur and tibia. Reproduced from Huo et al. ${ }^{(11)}$ with the permission of the Yale Journal of Biology and Medicine

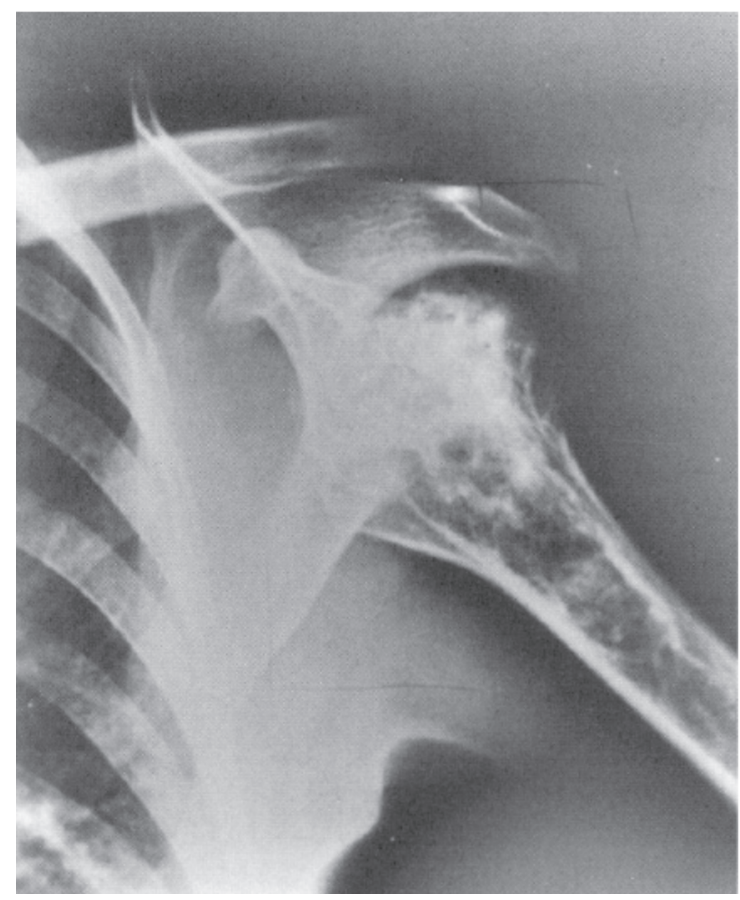

Figure 5 - X-ray showing osteonecrosis of the humeral head and bone infarction in patient with sickle cell disease. Reproduced from Huo et al. ${ }^{(11)}$ with the permission of the Yale Journal of Biology and Medicine 
Table 2 - Ficat classification for osteonecrosis of femur head in sickle cell disease

\begin{tabular}{cl}
\hline Stage & Image \\
\hline 0 & $\begin{array}{l}\text { Normal magnetic resonance imaging (necrosis can be seen } \\
\text { histologically) }\end{array}$ \\
I & Normal x-ray and CT; resonance shows necrosis and bone marrow \\
II & X-ray showing sclerosis and lytic lesions \\
III & X-ray showing flattening of the femoral head and a crescent sign \\
IV & X-ray showing collapse of the femoral head, articular space \\
& decrease, osteoarthritis
\end{tabular}

Adapted from Naoum \& Naoum ${ }^{(6)}$

Symptoms of shoulder movement limitations are absent in $80 \%$ of cases at diagnosis, however hip involvement, which usually has an insidious presentation, may have an acute presentation and simulate septic arthritis or synovitis. ${ }^{(6)}$ Osteonecrosis of the femoral head is often bilateral and the degree of osteonecrosis is determined by Ficat classification (Table 2). ${ }^{(6)}$

The prevalence and incidence of osteonecrosis of the femoral head was investigated in a study by Milner et al., ${ }^{(14)}$ in which 2590 patients were studied over a period of more than 5 years. At baseline, $9.8 \%$ of patients had osteonecrosis. Furthermore, patients with $\mathrm{Hb} \mathrm{SS}$ and $\alpha$-thalassemia were at a higher risk of developing this complication (4.5 cases per 100 patients/year, compared with 2.4 in patients with $\mathrm{Hb}$ SS without thalassemia and 1.9 in those with $\mathrm{Hb}$ SC). ${ }^{(14)}$ This same study group investigated the prevalence of necrosis of the humeral head in $2524 \mathrm{SCD}$ patients and showed that $5.6 \%$ of the investigated patients had radiological alterations at baseline. ${ }^{(15)}$

\section{Dactylitis}

Dactylitis, also known as 'hand-foot syndrome', is a complication of acute vaso-occlusive disease characterized by pain and edema on the dorsum of the hands or feet or both simultaneously, often accompanied by increased local temperature and erythema. ${ }^{(4,6)}$ Histologically, there are extensive areas of medullary infarction, with periosteal bone formation. ${ }^{(4)}$ In a retrospective study carried out in the United States, the incidence of dactylitis in children with SCD was $12 \%$; it was the first manifestation of SCD in $55 \%$ of 16 patients studied. ${ }^{(16)}$

Dactylitis usually manifests as self-limiting episodes, lasting one to two weeks and may recur, but rarely causes permanent joint sequelae. In acute crises, fever and leukocytosis can be observed, and a differential diagnosis must be made with juvenile arthritis and osteomyelitis. ${ }^{(6)}$

\section{Osteomyelitis}

Osteomyelitis is the most common type of joint infection in $\mathrm{SCD}$, found in up to $61 \%$ of patients. ${ }^{(7)}$ It is usually triggered by vaso-occlusive crises, but the clinical picture can be differentiated from acute ischemic painful crises by fever, which is usually higher in cases of infection. ${ }^{(13)}$ After episodes of bacteremia, bacteria commonly colonize areas that have suffered from bone ischemia. ${ }^{(7)}$

In a recent study by Hernigou et al. ${ }^{(17)}$ which included 2000 SCD patients, $59(3 \%)$ had septic arthritis mostly of the hip joint (61\%). The most common manifestations were pain, swelling, fever $\left(>38.2^{\circ} \mathrm{C}\right)$ and leukocytosis $\left(>15,000 / \mathrm{mm}^{3}\right)$. The joint aspirate cultures were positive in $96 \%$ of cases and were predominantly infections by Staphylococcus and Gram negative bacteria. Salmonella infection was not observed in this study. The risk factors identified were osteonecrosis and osteomyelitis in childhood. ${ }^{(17)}$

SCD patients have a predisposition to develop osteomyelitis by Salmonella. ${ }^{(18-20)}$ In a study of 35 SCD patients and osteoarticular alterations, positive blood cultures were observed in 18 and synovial fluid cultures, abscesses and positive biopsies in 23. The agent responsible for infection was Salmonella in 22 cases (71\%) and Staphylococcus aureus in $10(29 \%) .{ }^{(7)}$ Other less common causes of joint infection in SCD include Gram-negative enteric bacteria, Haemophilus influenzae, Escherichia coli and Mycobacterium tuberculosis. ${ }^{(4)}$

The predisposition of SCD patients to have infections, including osteomyelitis, has been attributed to several mechanisms, such as hyposplenism, impaired complement activity and the presence of bone with ischemia or necrosis. ${ }^{(4)}$ In SCD, the occlusion of capillaries facilitates the transudation of gastrointestinal bacteria, including Salmonella, into the bloodstream. ${ }^{(21)}$

Radiography is often normal in these cases, but may present signs as shown in Figure 6. All kinds of biological material should be sent for microbiological analysis as soon as possible, including blood, joint effusion aspirate and subperiosteal abscesses. ${ }^{(13)}$
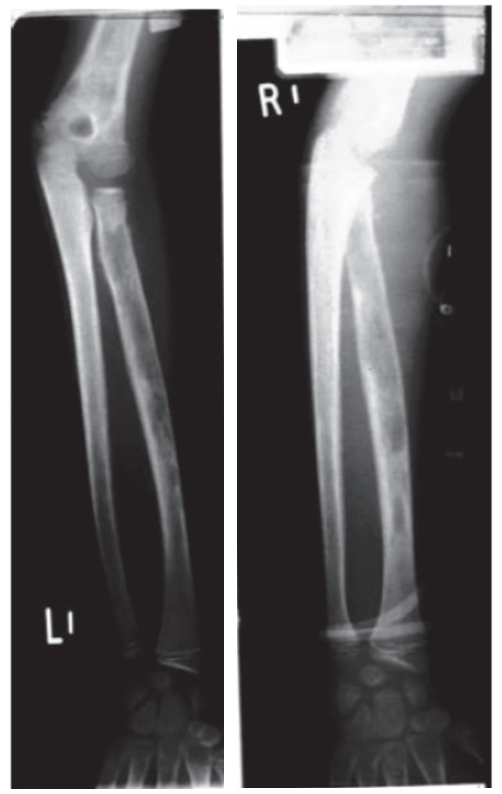

Figure 6 - X-ray of upper limb showing radial multifocal osteomyelitis in a patient with sickle cell disease. Reproduced from Almeida \& Roberts ${ }^{(4)}$ with permission of John Wiley and Sons 


\section{Osteopenia and osteoporosis}

Several studies have shown a decrease in bone mineral density in SCD attributed to bone marrow hyperplasia. ${ }^{(22-24)}$ Compared with normal subjects, Brinker et al. ${ }^{(22)}$ showed that SCD patients have lower bone mineral density; in particular, spinal column osteoporosis is common in SCD patients.

Radiologically, there is an increase in radiolucent vertebral bodies, prominent vertebral trabeculae, biconcave deformity or "fish-mouth" vertebrae, which appear as a result of compression of vertebrae by the adjacent intervertebral discs. ${ }^{(25)}$ There may be vertebral collapse, both as a result of osteoporosis or due to vertebral infarction. Vertebral collapse is usually asymptomatic and may require analgesia and mechanical support in the long-term. ${ }^{(4)}$

\section{Arthritis}

Several forms of arthritis, both inflammatory and noninflammatory, are described in association with SCD, including bone infarcts, hyperuricemia, gout and osteomyelitis, which may progress to destruction of important joint components and bone erosion. ${ }^{(26)}$ Cases of synovitis, with infiltration of plasma cells and evidence of joint destruction, have also been described in SCD. ${ }^{(27)}$

The arthritis associated with SCD is usually polyarticular (more than $80 \%$ of cases) and symmetric (over $60 \%$ of cases), with a predilection for large joints and lower extremities, generally lasting less than one week. ${ }^{(28)} \mathrm{X}$-rays can identify periarticular osteopenia, bone erosion, synovitis and joint space narrowing (Figure 7).

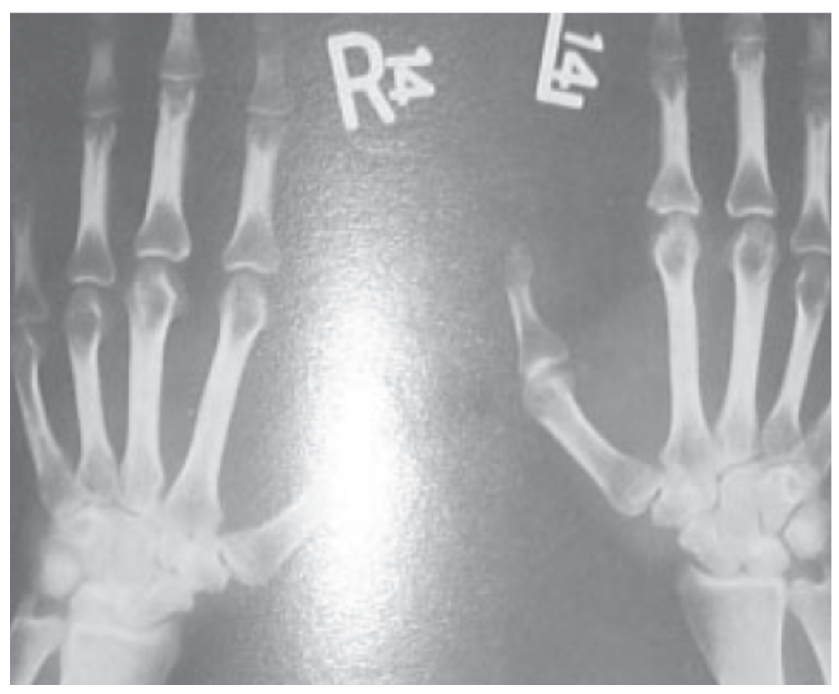

Figure 7 - X-ray of the hands of a patient with sickle cell disease and rheumatoid arthritis showing periarticular osteopenia, erosion of pyramidal and pisiform bones, left prestyloid synovitis, decreased joint space in the third left proximal interphalangeal joint and suspected synovitis in the third and fourth proximal right interphalangeal joints. Reproduced from Arana et al. ${ }^{(26)}$ with permission of the Asociación Colombiana de Reumatología e Asociación Centroamericana, Caribe \& Andina de Reumatología
Reports of gouty arthritis in SCD are rare. ${ }^{(29)}$ One possible explanation for this low incidence of gout in SCD patients is the occurrence of congestion and thrombosis of small vessels due to sickling of red blood cells, which prevents leukocytes in response to chemotactic stimulation of the deposition of crystals to reach the joint and also the fact that gout attacks require the presence of polymorphonuclear cells. ${ }^{(29)}$

Acute septic arthritis in SCD is also rare and is most commonly depicted as monoarthritis. ${ }^{(30)}$ Synovial effusion occurs in about $20 \%$ of acute attacks. The mechanism of arthropathy in SCD is a result of a reaction to bone infarcts and synovial ischemia. ${ }^{(31)}$ Erosive arthritis is a rare complication in SCD and is associated with the activation of neutrophils and phospholipase A2, as well as activation of vascular endothelium and triggering of a cascade of adhesion molecules such as vascular cell adhesion moleculars (VCAM), intercellular adhesion moleculars (ICAM), E-selectin and tissue factors. ${ }^{(26)}$ There are also reports of cases of juvenile arthritis with positive antinuclear factor in SCD patients, however this association remains poorly understood. ${ }^{(32)}$

\section{Connective tissue diseases}

The occurrence of connective tissue diseases, including rheumatoid arthritis and systemic lupus erythematosus has been rarely reported in SCD patients. ${ }^{(33-39)}$ SCD patients may be at greater risk of developing autoimmune diseases, as they present activation disorders of the alternative pathway of complement cascade. ${ }^{(40,41)}$

Recently, Michel et al., ${ }^{(42)}$ performed a study involving 2000 adults with SCD followed at an outpatient clinic, showing that connective tissue diseases were diagnosed in 30 patients. The prevalence of rheumatoid arthritis was $0.75 \%$ and of lupus, $0.35 \%$. Usually the prevalence of rheumatoid arthritis in individuals of African descent is less than $0.5 \%$, and the prevalence of lupus is considered to be eight times higher in individuals of African descent than in other populations, which would explain the high prevalence of lupus found in the study, but not rheumatoid arthritis, which was greater than that observed in the general population. ${ }^{(43-45)}$

In the study by Michel et al., ${ }^{(42)}$ the authors diagnosed rheumatoid arthritis in 15 cases, systemic lupus erythematosus in 13, Sjögren's syndrome with central nervous system involvement in one and systemic sclerosis in one case. Rheumatoid factor was detected in 14 of the 15 patients with rheumatoid arthritis (93\%) and anti-citrulline peptide in $88 \%$. Antinuclear factor was detected in nine patients and anti-Ro/SSA in two cases. Anti-DNA was detected in only one case. Steroid treatment was administered to 25 patients $(83 \%)$ and $15(50 \%)$ received at least one immunosuppressant (methotrexate in 14 cases). Anti-TNF agent was administered to four patients with rheumatoid arthritis and one received rituximab without exacerbation of the SCD. After a mean follow-up of 4.5 years, 


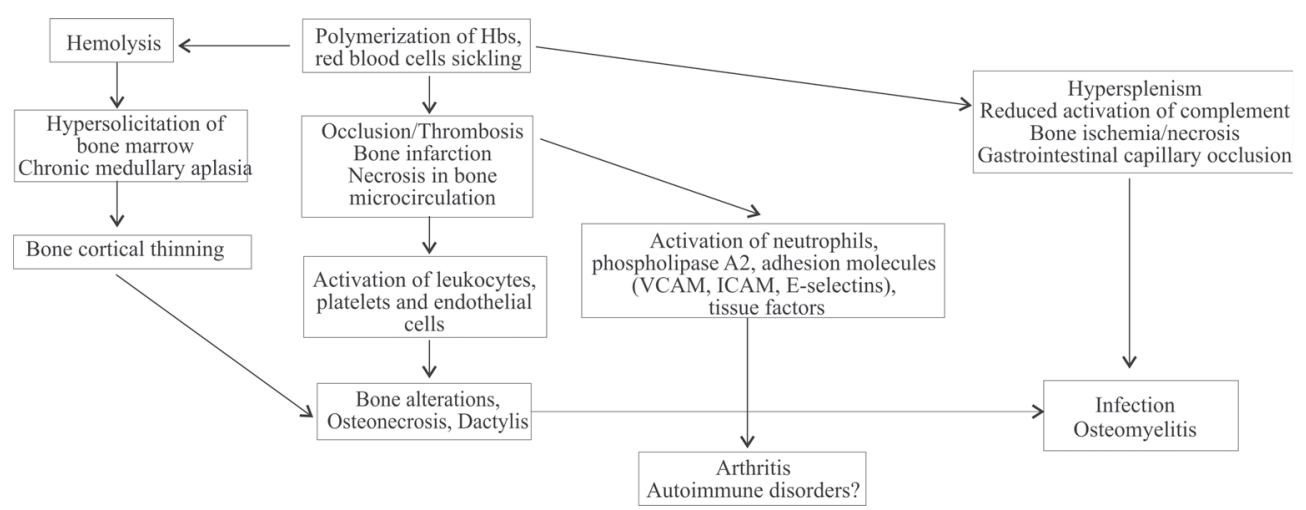

Figure 8 - Pathophysiology of osteoarticular involvement in sickle cell disease

11 of $25(44 \%)$ who were receiving steroids had at least one episode of severe infection (mostly caused by Staphylococcus aureus or Escherichia coli).

SCD exacerbation was observed in 13 of 30 cases (43\%) after the onset of connective tissue disease; 12 of these were receiving prednisone and/or methotrexate, six patients $(20 \%)$ died due to sepsis $(n=2)$, stroke $(n=2)$ or acute chest syndrome $(\mathrm{n}=2)$. The authors concluded that the connective tissue diseases associated with SCD did not imply greater severity in the studied patients. However, patients with active disease of connective tissues receiving steroids with or without methotrexate had more severe manifestations of SCD, more frequent infections and higher mortality. It is suggested that SCD patients and connective tissue diseases should have the risk-benefit evaluated before starting treatment and regimens with lower doses of steroids should be preferred. ${ }^{(42)}$

The physiopathology of osteoarticular involvement is shown in Figure 8.

\section{Treatment}

The treatment of SCD includes preventive measures for some complications and three main strategies: chronic blood transfusions, hydroxyurea and bone marrow transplantation. ${ }^{(1)}$ The outpatient care of patients aims at sporadic evaluation of the organs and systems in order to detect any early alterations and advising patients and their families about the disease. ${ }^{(46)}$

As the vaso-occlusive events may be precipitated by infection, fever, dehydration, acidosis, hypoxia, and exposure to cold, measures to prevent these events are important in the management of SCD patients. The treatment of painful crises should be carried out with hydration and analgesia; dipyrone, paracetamol, non-steroidal anti-inflammatory drugs (NSAIDs) or opioid derivatives can be used, always taking into account that the latter should be used with caution due to renal impairment. ${ }^{(47)}$ Proper hydration is extremely important, especially in the case of fever.

The use of drugs that stimulate the production of $\mathrm{Hb} F$ is beneficial in SCD. This therapeutic strategy is based on the observation that in the neonatal period, the clinical expression of the $\mathrm{Hb} \mathrm{S}$ gene is inhibited by the presence of $\mathrm{Hb}$ F. Hydroxyurea, a cytotoxic drug with no effect on DNA methylation, increases $\mathrm{Hb} \mathrm{F}$ production and is associated with increased survival. ${ }^{(47)}$ This drug prevents the maturation of erythroid precursors, resulting in the recruitment of erythroid progenitors with greater capacity for $\mathrm{Hb} \mathrm{F}$ synthesis and even has a possible effect of 'reprogramming' the synthesis of hemoglobin in erythroid progenitors. ${ }^{(1)}$ The benefits observed with the use of hydroxyurea include reduced vaso-occlusive episodes and painful crises, increased interval between episodes of pain, fewer episodes of acute chest syndrome, and reduced need for blood transfusions and hospitalization. ${ }^{(48,49)}$

The treatment of osteonecrosis may be conservative or surgical. In the early stages, the conservative medical treatment can be performed, which consists of rest, reducing weight overload on the joints, administration of analgesics and non-steroidal anti-inflammatory drugs and hydrotherapy. Physical therapy strengthens the muscles of the hip and thighs, reduces local muscle spasms and helps correct posture. ${ }^{(6)}$ In advanced stages, the main treatment of osteonecrosis of the femoral head is arthroplasty with prostheses and the prognosis is less favorable than that observed in arthroplasties of other etiologies. ${ }^{(6)}$ The use of the prostheses is made difficult by the presence of severe bone sclerosis. After surgery, about two thirds of patients remain with pain and three quarters have limited movement. ${ }^{(6)}$

Some more recent studies have shown good results with hip replacement surgery in SCD patients. ${ }^{(50)}$ Surgical decompression or arthroplasty have also been suggested as a good option for the treatment of osteonecrosis in SCD. ${ }^{(12,51)}$.

The treatment of dactylitis is carried out with local care and therapy of symptomatic (analgesics and NSAIDs) as the clinical picture is usually self-limiting. ${ }^{(6)}$

Cases of joint infection and osteomyelitis should be treated with antibiotics and analgesia. The most commonly used antibiotics are cephalosporins, including cefotaxime and ceftriaxone, for an average period of 10 days. ${ }^{(13)}$ Surgical drainage and cleaning are necessary in cases of abscesses. $^{(13)}$ 
In the case of rheumatoid arthritis associated with SCD, as there is an inflammatory process associated with endothelial alterations, sulfasalazine can be used in addition to NSAIDs, as it is a potent inhibitor of factor NF-kB, which is associated with the gene expression of pro-coagulant and pro-adhesive molecules on the endothelium. ${ }^{(26)}$

Anti-TNF agents can also be used for their role in controlling inflammation and in the expression of adhesion molecules in the vascular endothelium. The use of methotrexate is limited in SCD because of the high frequency of liver abnormalities caused by the disease itself, which would be exacerbated by the hepatotoxicity of this drug. ${ }^{(26)}$ The use of intra-articular corticosteroids is not recommended in SCD, as this may precipitate or prolong painful crises. ${ }^{(52)}$ Pain control in cases of arthritis associated with SCD has also been carried out with opioid derivatives (tramadol), with good results. ${ }^{(32)}$

New therapeutic options have been studied for SCD and have shown good results. Inhibitors of histone deacetylase (HDAC), which inhibit the adhesion of erythrocytes to the endothelium, showed a reduction in vascular complications in SCD. ${ }^{(53)}$ Butyrate is a fatty acid known to induce the expression of genes that has been used in SCD patients and showed to increase the production of $\mathrm{Hb} \mathrm{F}$ in some studies. ${ }^{(54,55)}$ Trichostatin A was tested in animal models and shown to increase the concentration of $\mathrm{Hb} \mathrm{F}$ and inhibit the expression of cell adhesion molecules. ${ }^{(56)}$
Decitabine and senicapoc (ICA-17043), drugs that belong to the Gardos channel blocker class, reduce the polymerization of $\mathrm{Hb} \mathrm{S}$, preventing dehydration of red blood cells. ${ }^{(56,57)}$

Inhaled nitric oxide has been proposed as a treatment for painful crises, especially for acute chest syndrome and randomized studies are being conducted to prove its effectiveness. ${ }^{(56)}$ L-arginine, sildenafil and tetrahydrobiopterin ( $\mathrm{BH} 4)$ have been studied as potential treatments for SCD, all of which are related to increases in NO levels. ${ }^{(56)}$

There is increasing evidence that oxidative stress plays an important role in the pathophysiology of complications of SCD and therefore, the therapeutic potential of several antioxidants in this disease has been suggested, including arginine, statins, corticosteroids, sulfasalazine, iron chelators, $\mathrm{N}$-acetylcysteine, fermented papaya preparations, NSAIDs, allopurinol, among others. ${ }^{(56,58)}$ The use of intravenous immunoglobulin has been tested in experimental studies and shown to reduce the number of leukocytes adherent to the endothelium, the number of erythrocytes interacting with leukocytes and to improve microcirculation in rats subjected to painful crises. ${ }^{(56)}$

SCD patients have a deficiency of several vitamins, including zinc, vitamin $\mathrm{C}$, vitamin $\mathrm{E}$, acetylcysteine, calcium, vitamin $\mathrm{D}$ and vitamin $\mathrm{A}$ and there is evidence of the benefit of calcium, vitamin D and zinc supplementation. ${ }^{(59)}$ High doses of vitamin D (50,000 IU 2x/week) have shown to reduce chronic pain in SCD, according to a recently published case report. ${ }^{(60)}$

\begin{tabular}{|c|c|c|c|c|c|c|c|}
\hline Reference & $\begin{array}{l}\text { Number } \\
\text { of cases }\end{array}$ & $\begin{array}{l}\text { Age } \\
\text { (years) }\end{array}$ & Gender & $\begin{array}{l}\text { Type of sickle } \\
\text { cell disease }\end{array}$ & Clinical manifestations & Diagnosis & Treatment \\
\hline Worrall et al. ${ }^{(16)}$ & 9 & $\begin{array}{l}\text { Mean: } 18.2 \\
(5-42)\end{array}$ & $\begin{array}{r}7 \mathrm{M} \\
2 \mathrm{~F}\end{array}$ & $\begin{array}{l}\text { Hb SS }(88 \%) \\
\text { Hb SC }(12 \%)\end{array}$ & $\begin{array}{l}\text { Fever, leukocytosis, anemia, } \\
\text { pain, edema }\end{array}$ & Dactylitis & $\begin{array}{l}\text { Analgesics, } \\
\text { antibiotics }\end{array}$ \\
\hline Schumacher et al. ${ }^{(27)}$ & 2 & $19-33$ & $\begin{array}{r}1 \mathrm{M} \\
1 \mathrm{~F}\end{array}$ & & $\begin{array}{l}\text { Arthritis in elbow and wrist, } \\
\text { joint movement limitation, } \\
\text { destruction of joint cartilage }\end{array}$ & Chronic synovitis & Analgesics \\
\hline Rothschild et al. ${ }^{(29)}$ & 2 & $28-49$ & M & $\mathrm{Hb} \mathrm{SS}$ & $\begin{array}{l}\text { Interphalangeal, wrist, elbow, } \\
\text { shoulder, knee arthritis }\end{array}$ & Gout & NSAIDs \\
\hline Bennet \& Namnyak. ${ }^{(7)}$ & 57 & $\begin{array}{l}\text { Mean: } 15.7 \\
\text { (10 months } \\
\text { to } 46 \text { years) }\end{array}$ & $\begin{array}{r}32 \mathrm{M} \\
25 \mathrm{~F}\end{array}$ & $\mathrm{Hb} \mathrm{SS}$ & $\begin{array}{l}\text { Arthralgia/Arthritis }(80.7 \%) \text {, } \\
\text { joint effusion }(14 \%), \\
\text { hemarthrosis }(3.5 \%)\end{array}$ & $\begin{array}{l}\text { Osteonecrosis }(74 \%), \\
\text { Osteomyelitis }(61.4 \%) \text {, } \\
\text { Septic Arthritis }(7 \%) \text {, }\end{array}$ & $\begin{array}{l}\text { Analgesics, } \\
\text { antibiotic therapy, } \\
\text { Surgery hip art. }\end{array}$ \\
\hline Eberhard. ${ }^{(32)}$ & 1 & 16 & $\mathrm{~F}$ & $\mathrm{Hb} \mathrm{SS}$ & $\begin{array}{l}\text { Pain and edema in interphalangeal, } \\
\text { elbow and hip joints, limitation of } \\
\text { joint movement, }\end{array}$ & $\begin{array}{l}\text { Mixed connective tissue } \\
\text { disease }\end{array}$ & $\begin{array}{l}\text { NSAIDs, } \\
\text { hydroxychloroquine, } \\
\text { prednisone, tramadol }\end{array}$ \\
\hline Alonge et al. ${ }^{(51)}$ & 5 & $\begin{array}{l}\text { Mean: } 31.8 \\
(22-34)\end{array}$ & $\begin{array}{r}2 \mathrm{M} \\
3 \mathrm{~F}\end{array}$ & $\begin{array}{l}\text { Hb SS }(80 \%) \\
\text { Hb SC }(20 \%)\end{array}$ & Hip joint pain & Osteonecrosis & Arthroplasty \\
\hline Arana et al. (26) & 1 & 36 & $\mathrm{~F}$ & $\mathrm{Hb} \mathrm{SS}$ & $\begin{array}{l}\text { Joint pain in elbows knees, ankles, } \\
\text { temporomandibular joint, proximal } \\
\text { inter-phalangeal joints, edema, joint } \\
\text { movement limitation }\end{array}$ & Rheumatoid Arthritis & $\begin{array}{l}\text { NSAIDs, } \\
\text { prednisolone, } \\
\text { folic acid, } \\
\text { acetaminophen }\end{array}$ \\
\hline Aslanidis et al. ${ }^{(30)}$ & 1 & 32 & $\mathrm{~F}$ & $\mathrm{Hb} \mathrm{SS}$ & Pain and edema in right elbow & Bone Infarction & NSAIDs \\
\hline Michel et al. ${ }^{(42)}$ & 30 & Mean: 37 & $\begin{array}{l}7 \mathrm{M} \\
23 \mathrm{~F}\end{array}$ & $\begin{array}{l}\text { Hb SS }(83 \%) \\
\mathrm{Hb} \mathrm{SC}(17 \%)\end{array}$ & $\begin{array}{l}\text { Arthritis, osteonecrosis, } \\
\text { osteomyelitis, extra-articular } \\
\text { manifestations }\end{array}$ & $\begin{array}{l}\text { Rheumatoid Arthritis }(50 \%) \\
\text { SLE }(10 \%) \\
\text { Jögren Sd. }(3.3 \%) \\
\text { Systemic sclerosis }(3.3 \%)\end{array}$ & $\begin{array}{l}\text { Prednisone } \\
\text { Methotrexate } \\
\text { Anti-TNFa } \\
\text { Rituximab }\end{array}$ \\
\hline Gregg \& Alexander. ${ }^{(63)}$ & 1 & 11 & M & $\mathrm{Hb} \mathrm{SS}$ & Pain in right shoulder, fever & Osteomyelitis (C. difficile) & Antibiotics \\
\hline Hernigou et al. ${ }^{(17)}$ & 59 & & $\begin{array}{r}39 \mathrm{M} \\
20 \mathrm{~F}\end{array}$ & $\begin{array}{l}\text { Hb SS }(95 \%) \\
\text { Hb SC }(3 \%) \\
\text { Hb SB }(2 \%) \\
\end{array}$ & Joint pain and edema, fever & $\begin{array}{l}\text { Septic arthritis }(100 \%) \\
\text { Osteonecrosis }(49 \%) \\
\text { Osteomyelitis }(62 \%) \\
\end{array}$ & Antibiotics \\
\hline
\end{tabular}

*M: Male, F: Female, NSAIDs; Non-steroidal anti-inflammatory drugs 
It is known that the coagulation system is activated in $\mathrm{SCD}$, but the role of thrombogenesis in vaso-occlusive episodes is still uncertain. Some studies have been carried out with heparin, oral anticoagulants and acetylsalicylic acid has been shown to be beneficial in preventing thrombotic events, but its use is still controversial and further studies are needed to establish the role of this therapy in SCD. ${ }^{(59)}$

Bone marrow transplant was first performed in SCD more than 25 years ago and it is the only currently available potentially curative treatment, having shown good results, especially in recent years. ${ }^{(1,49,61)}$ Gene therapy holds promise as a potential cure for SCD. Recently, through in situ genetic engineering, correction of the genetic mutation in SCD has been demonstrated, using pluripotent stem cells. ${ }^{(62)}$

Table 3 summarizes the clinical characteristics and treatment of major literature-reported cases of osteoarticular involvement in SCD.

\section{Conclusion}

Osteoarticular involvement is common in SCD, showing high morbidity and being among the most common reasons for patients to go to emergency services. The treatment of these complications is mostly symptomatic; more detailed studies are needed to understand the pathophysiological mechanisms involved in the development of complications and propose more appropriate and specific therapies.

\section{References}

1. Wang WC. Sickle cell anemia and other sickling syndromes. In: Greer JP, Foerster J, Rodgers GM, Paraskevas F, Glader B, Arber DA, Means Jr RT, editors. Wintrobe's Clinical Hematology. 12th ed. Philadelphia: Lippincott Williams \& Wilkins; 2009. p.103882.

2. Schnog JB, Duits AJ, Muskiet FA, ten Cate H, Rojer RA, Brandjer DP. Sickle cell disease: a general overview. Neth J Med. 2004;62 (10):364-73.

3. Loureiro MM, Rozenfeld S. [Epidemiology of sickle cell disease hospital admissions in Brazil]. Rev Saúde Pública. 2005;39(6):9439. Portuguese.

4. Almeida A, Roberts I. Bone involvement in sickle cell disease. $\mathrm{Br}$ J Haematol. 2005; 129(4):482-90. Comment in: Br J Haematol. 2006;133(2):212-4.

5. Babela JR, Nzingoula S, Senga P. [Sicke-cell crisis in the child and teenager in Brazzaville, Congo. A retrospective study of 587 cases] Bull Soc Pathol Exot. 2005;98(5):365-70. French.

6. Naoum PC, Naoum FA. Doença das células falciformes. São Paulo: Sarvier; 2004. 222 p.

7. Bennett OM, Namnyak SS. Bone and joint manifestations of sickle cell anaemia. J Bone Joint Surg. 1990;72(3):494-9.

8. Smith JA. Bone disorders in sickle cell disease. Hematol Oncol Clin North Am. 1996;10(6):1345-56.

9. Rubin JE, Rubin CT. Biology, physiology, and morphology of bone. In: Firestein GS, Budd RC, Harris Jr ED, McInnes IB, Ruddy S, Sergent JS, editors. Kelley`s Textbook of Rheumatology. 8th ed. Philadelphia: Saunders Elsevier; 2009. p. 71-91.

10. Mohammed SM. Calcium metabolism in sickle cell disease: possible link with sicklaemic osteoporosis[thesis]. London: University of Salford; 1991.
11. Huo MH, Friedlaender GE, Marsh JS. Orthopaedic manifestations of sickle cell disease. Yale J Biol Med. 1990;63(3):195-207.

12. Mukisi-Mukaza M, Manicom O, Alexis C, Bashoun K, Donkerwolcke M, Burny F. Treatment of sickle cell disease's hip necrosis by core decompression: a prospective case-control study. Orthop Traumatol Surg Res. 2009;95(7):498-504.

13. Mary P. [Sickle cell disases as a cause of osteoarthritis]. Arch Pediatr. 2008;15(5):639-41. French.

14. Milner PF, Kraus AP, Sebes JI, Sleeper LA, Dukes KA, Embury SH, et al. Sickle cell disease as a cause of osteonecrosis of the femoral head. N Engl J Med. 1991;325(21):1476-81.

15. Milner PF, Kraus AP, Sebes JI, Sleeper LA, Dukes KA, Embury SH, et al. Osteonecrosis of the humeral head in sickle cell disease. Clin Orthop Relat Res. 1993;(289):136-43.

16. Worrall VT, Butera V. Sickle cell dactylitis. J Bone Joint Surg. 1976;58(8):1161-3.

17. Hernigou P, Daltro G, Flouza-Lachaniette $\mathrm{CH}$, Roussignol X, Poignard A. Septic arthritis in adults with sickle cell disease often is associated with osteomyelitis or osteonecrosis. Clin Orthop Relat Res. 2010;468(6):1676-81.

18. Borret-Connor E. Bacterial infection and sickle cell anaemia. An analysis of 250 infections in 166 patients with a review of the literature. Medicine (Baltimore). 1971;50(2):97-112.

19. Engh CA, Hugher JL, Abrams RC, Bowerman JW. Osteomyelitis in the patient with sickle cell disease: diagnosis and management. J Bone Joint Surg Am. 1971;53(1):1-15.

20. Adeyokunnu AA, Hendrickse RG. Salmonella osteomyelitis in childhood: a report of 63 cases seen in Nigerian children of whom 57 had sickle cell anaemia. Arch Dis Child. 1980;55(3):175-84.

21. Anand AJ, Glatt AE. Salmonella osteomielitis and arthritis in sickle cell disease. Semin Arthritis Rheum. 1994;24(3):211-21.

22. Brinker MR, Thomas KA, Meyers SJ, Texada T, Humbert JR, Cook SD, et al. Bone mineral density of the lumbar spine and proximal femur is decreased in children with sickle cell anemia. Am J Orthop (Belle Mead NJ). 1998;27(1):43-9.

23. Vanderjagt DJ, Bonnett C, Okolo SN, Glew RH. Assessment of the bone status of Nigerian children and adolescents with sickle cell disease using calcaneal ultrasound and serum markers of bone metabolism. Calc Tissue Int. 2002;71(2):133-40.

24. Nelson DA, Rizvi S, Bhattacharyya T, Ortega J, Lachant N, Swerdlow P. Trabecular and integral bone density in adults with sickle cell disease. J Clin Densitom. 2003;6(2):125-9.

25. Williams HJ, Davies AM, Chapman S. Bone within a bone. Clin Radiol. 2004;59(2):132-44.

26. Arana B, Gudiño PA, Cruz EA. Probable artritis reumatoide en un paciente con enfermedad de células falciformes. Rev Colomb Reumatol. 2006;13:86-90.

27. Schumacher HR, Dorwart BB, Bond J, Alavi A, Miller W. Chronic synovitis with early cartilage destruction in sickle cell disease. Ann Rheum Dis. 1977;36(5):413-9.

28. Espinoza LR, Spilberg I, Osterland CK. Joint manifestations of sickle cell disease. Medicine (Baltimore). 1974;53(4):295-305.

29. Rothschild BM, Sienknecht CW, Kaplan SB, Spindler JS. Sickle cell disease associated with uric acid deposition disease. Ann Rheum Dis. 1980;39(4):392-5.

30. Aslanidis S, Pyrpasopoulou A, Perifanis V, Kartali N, Zamboulis C. Acute arthritis in sickle cell anaemia: rare presentation of a peripheral bone infarct. Eur J Haematol. 2006;77(1):89.

31. Klippel JH. Artropatias asociadas a trastornos hematológicos y malignos. In: Altman D. Princípios de enfermedades reumáticas. $11^{\circ}$ ed. Ciudad de México: Intersistemas; 1997. p. 383-7.

32. Eberhard BA. Coexistent sickle cell disease and juvenile rheumatoid arthritis: 2 cases with delayed diagnosis and severe destructive 
arthropathy. J Rheumatol. 2002;29(8):1802; author reply 1802-3. Comment on: J Rheumatol. 2001;28(9):2125-8.

33. Katsanis E, Hsu E, Luke KH, McKee JA. Systemic lupus and sickle hemoglobinopathies: a report of two cases and review of literature. Am J Hematol. 1987;25(2):211-4.

34. Marino C, McDonald E. Rheumatoid arthritis in a patient with sickle cell disease. J Rheumatol. 1990;17(7):970-2.

35. Eissa MM, Lawrence JM 3rd, McKenzie L, Little FM, Mankand VN, Yang YM. Systemic lupus erythematosus in a child with sickle cell disease. South Med J. 1995;88(11):1176-8.

36. Shetty AK, Kumart SR, Gedalla A, Warrier RP. Sickle cell anemia with systemic lupus erythematosus; response to hydroxyurea therapy. J Pediatr Hematol Oncol. 1998;20(4):335-7.

37. Kaloterakis A, Filitou A, Haziyannis S, Vaiopoulos G, LutradiAnagnostou A. Sickle cell/ $\beta$ [sup o]-thalassemia and systemic lupus erythematosus. Lupus. 1999;8(9):778-9.

38. Nistala K, Murray KJ. Co-existent sickle cell disease and juvenile rheumatoid arthritis. Two cases with delayed diagnosis and severe destructive arthropathy. J Rheumatol. 2001;28 (9):2125-8. Comment in: J Rheumatol. 2002;29(8):1802; author reply 1802-3.

39. Khalidi NA, Ajmani H, Varga J. Coexisting systemic lupus erythematosus and sickle cell disease: a diagnostic and therapeutic challenge. J Clin Rheumatol. 2005;11(2):86-92.

40. Koethe SM, Casper JT, Rodey GE. Alternative pathway activity in sera from patients with sickle cell disease. Clin Exp Immunol. 1976;23(1):56-60.

41. Wilson WA, De Ceulaer K, Morgan AG. Sickle cell anemia, complement and systemic lupus erythematosus. Arthritis Rheum. 1979;22(7):803.

42. Michel M, Habibi A, Godeau B, Bachir D, Lahary A, Galacteros F, et al. Characteristics and outcome of connective tissue diseases in patients with sickle cell disease: report of 30 cases. Semin Arthritis Rheum. 2008;38(3):228-40.

43. MacGregor AJ, Riste LK, Hazes JM, Silman AJ. Low prevalence os rheumatoid arthritis in black-Caribbeans compared with whites in inner city Manchester. Ann Rheum Dis. 1994;53(5):293-7. Comment in: Ann Rheum Dis. 1996;55(4):272.

44. Molokhia M, McKeigue P. Risk for rheumatic disease in relation to ethnicity and admixture. Arthritis Res. 2000;2(2):115-25.

45. Molokhia M, McKeigue PM, Cuadrado M, Hugher G. Systemic lupus erythematosus in migrants from west Africa compared with Afro-Caribbean people in the UK. Lancet. 2001;357(9266):14145. Comment in: Lancet. 2001;358(9288):1182.

46. Braga JA. Medidas gerais no tratamento das doenças falciformes. Rev Bras Hematol Hemoter 2007;29(3):233-8.

47. Brunetta DM, Clé DV, Haes TM, Roriz Filho JS, Moriguti JC. Manejo das complicações agudas da doença falciforme. Medicina (Ribeirão Preto). 2010;43(3):231-7.

48. Saunthararajah Y, Vichinsky EP. Sickle cell disease: clinical features and management. In: Hoffman R, Furie B, McGlave P, Silbertein LE, Shattil SJ, Benz Jr EJ, et al. Hoffman - Hematology: basic principles and practice. Oxford: Churchill Livingstone, 5th edition; 2008. p.577-601.

49. Rees DC, Williams TN, Gladwin MT. Sickle cell disease. Lancet. 2010;376(9757):2018-31.

50. Ekere AU, Eze CB, Ebirim LN. A report of two cases of uncemented total hip replacement in patients with sickle cell disease. Niger J Clin Pract. 2008;11(3):257-9.

51. Alonge TO, Shokunbi WA. The choice of arthroplasty for secondary osteoarthritis of the hip joint following avascular necrosis of the femoral head in sicklers. J Natl Med Assoc. 2004;96(5):678-81.

52. Gladman DD, Bombardier C. Sickle cell crisis following intraarticular steroid therapy for rheumatoid arthritis. Arthritis Rheum. 1987;30(9):1065-8

53. Hebbel RP, Vercellotti GM, Pace BS, Solovey AN, Kollander R, Abanonu CF, et al. The HDAC inhibitors trichostatin A and suberoylanilide hydroxamic acid exhibit multiple modalities of benefit for the vascular pathobiology of sickle transgenic mice. Blood. 2010;115(12):2483-90.

54. Sher GD, Ginder GD, Little J, Yang S, Dover GJ, Olivieri NF. Extended therapy with intravenous arginine butyrate in patients with beta-hemoglobinopathies. N Engl J Med. 1995;332(24):160610. Comment in: N Eng1 J Med. 1995;333(19):1287-8.

55. Pace BS, Chen YR, Thompson A, Goodman SR. Butyrate-inducible elements in the human gamma-globulin promoter. Exp Hematol. 2000;28(3):283-93.

56. Ataga KI. Novel therapies in sickle cell disease. Hematology Am Soc Hematol Educ Program. 2009;54-61.

57. Stocker JW, De Franceschi L, McNaughton-Smith GA, Corrocher R, Beuzard Y, Brugnara C. ICA-17043, a novel Gardos channel blocker, prevents sickled red blood cell dehydration in vitro and in vivo in SAD mice. Blood. 2003;101(6):2412-8.

58. Nur E, Biemond BJ, Otten HM, Brandjes DP, Schnog JJ, CURAMA Study Group. Oxidative stress in sickle cell disease; pathophysiology and potential implications for disease management. Am J Hematol. 2011;86(6):484-9.

59. Saunthararajah Y, Vichinsky EP. Sickle cell disease - clinical features and management. In: In: Hoffman R, Furie B, McGlave P, Silbertein LE, Shattil SJ, Benz Jr EJ, et al. Hoffman - Hematology: basic principles and practice. 5th edition. Oxford: Churchill Livingstone; 2008. p. 577-601.

60. Osunkwo I. Complete resolution of sickle cell chronic pain with high dose vitamin D therapy: a case report and review of the literature. J Pediatr Hematol Oncol. 2011;33(7):549-51.

61. Al Jefri AH. Advances in allogeneic stem cell transplantation for hemoglobinopathies. Hemoglobin. 2011;35(5-6):469-75.

62. Sebastiano V, Maeder ML, Angstman JF, Haddad B, Khayter C, Yeo DT, et al. In situ genetic correction of the sickle cell anemia mutation in human induces pluripotent stem cells using engineered zinc fingers nucleases. Stem Cells. 2011;29(11):1717-26.

63. Gregg KS, Alexander KA. Native joint septic arthritis caused by Clostridium difficile in an 11-year old with SS disease. Pediatr Infect Dis J. 2009;28(29):853. 